\title{
Re-thinking Catholic Philosophy: Alasdair Maclntyre and the Tension within Thomism
}

Jovito V. Cariño

\begin{abstract}
Through Leo XIII's Aeterni Patris, Thomism became the staple Catholic response against the threats of modernity. Two things immediately ensued as a result of this papal intervention: the revival of Thomistic philosophy, and with this revival, the transformation of the same as a polemical tool. While it serves well the Catholic Church's campaign for orthodoxy, it is arguable however whether such polemical shift has philosophical merit, or if it has, whether it is compatible with the tradition of doing philosophy championed by Thomas Aquinas himself. This tension within Thomism, I believe, warrants the necessity of Catholic philosophy represented by Thomism to be rethought. The goal of such rethinking, it should be emphasized, is not to undermine the gains of Thomism's revival but to locate more precisely the critical potential of Aquinas' philosophy against modernity's philosophic claims. In this paper, I will adopt Alasdair MacIntyre's hermeneutics of the aforementioned problematic, and towards the end, I will indicate the possibility of an alternative mode of reviving Thomism. First, I will rehearse the basic claims of modernity. In the ensuing part, I will show the hermeneutic conflicts that render it impossible to tell the story of modernity in a single narrative. This is followed by an account of Kant's attempt to resolve the crisis of modernity by reinstating reason in its primacy. By employing MacIntyre's tradition-constituted rationality, I will then show the divide between Kant's and Aquinas' philosophy and how the oversight of such divergence led modern Thomists to misconceive the possibility of compromise between the two. Towards the end, I will narrate the complicity, albeit the inadvertent nature, of the Kantian project with the revival of Thomism, thus posing the necessity of selfcritique on the part Catholic philosophy.
\end{abstract}

Keywords: Thomism, enlightenment, modernity, reason 
192 MACINTYRE AND THE TENSION WITHIN THOMISM

\section{Introduction}

7 The term "enlightenment" as a philosophical tradition is as tricky as its kindred concept, "modern." For one, historically speaking, there is not just one but multiple versions of Enlightenment from the seventeenth century up to the early part of the nineteenth century: there were the French Enlightenment, the Scottish Enlightenment and the German Enlightenment to which Kant belonged. ${ }^{1}$ In his book After Virtue, MacIntyre used the term in its inclusive sense, hence the reference to all the major players in all three traditions when discussing Enlightenment. ${ }^{2}$

The Enlightenment is generally characterized as an intellectual and cultural phenomenon that puts the primacy of human reason be it in the form of mathematics, science, ethics, or rational theology. It is true that reason has always been the preoccupation of European philosophy since the earliest Greek thinkers but as a distinct historical episode, Enlightenment marks itself off from the preceding epochs for its abiding confidence in reason that grounds itself on nothing but its own. The acknowledged father of modernity, René Descartes, had intimated this in his earlier attempt to refound philosophy anew on cogito, but his efforts, though innovative during his time, still lacked the radicality that one would find in later modern thinkers like Denis Diderot, David Hume, Immanuel Kant, and G.W.F. Hegel. ${ }^{3}$ To put it another way, while in his time, Descartes and his contemporaries found the final arbiter of reality in reason, during the Enlightenment, it was precisely such function of reason that was put into question. ${ }^{4}$ In the hands of Kant however, reason reacquired its pole position, launching a philosophical heritage that run in conflict with the Catholic philosophic tradition which always considers reason as ancillary to faith or at least in conjunction with it. Catholic thinkers find in Kant's transcendental philosophy a huge challenge given the extent of its impact on a wide range of intellectual disciplines. Leo XIII, through Aeterni Patris and its endorsement of Thomism, would have wanted to mitigate the deleterious effects of excessive confidence on reason that one finds in Kant. Before turning, however, to the engagement of modern Thomists in this undertaking, I wish to revisit the early precursors of critique of reason and their contributions to the modern philosophic debates.

1 Stuart Brown, ed. British Philosophy and the Age of Enlightenment (New York: Routledge, 1996); Peter Reill and Ellen Judy Wilson, Encyclopedia of Enlightenment (New York: Facts on File, Inc., 2004).

2 See Alasdair MacIntyre, After Virtue: A Study in Moral Theory (Indiana: University of Notre Dame Press, 2007), 36-78.

${ }^{3}$ For a perspective on Descartes' relation with Enlightenment, see Peter A. Schouls, Descartes and The Enlightenment (United Kingdom: Edinburgh University Press, 1989), 63-76.

${ }^{4}$ Jean Le Rond D'Alembert, Preliminary Discourse to the Encyclopedia of Diderot, trans. by Richard N. Schwab (Chicago: University of Chicago Press, 1995), 5.

(c) 2016 Jovito V. Cariño

http://www.kritike.org/journal/issue 19/carino december2016.pdf

ISSN 1908-7330

$((c))$ BY-NC-ND 


\section{The Critique of Reason: The Pioneers}

Enlightenment thinkers made distinction between reason as a faculty of criticism and reason as a power of explanation. ${ }^{5}$ The prime representatives of the former were David Hume and Jean-Jacques Rousseau while for the latter, the best exponent was Isaac Newton. Hume was a Scot, and though one of the leading figures in the Scottish Enlightenment, he is nevertheless considered a subversive of his own tradition. His subversion consisted of his repudiation of the normative function of rationality, contrary to the belief of the Scottish philosophic tradition, and his turn towards a more liberal approach to ethical theory, an orientation that was more Anglicized rather than Scottish. ${ }^{6}$ Concerning reason, Hume was a thorough skeptic ${ }^{7}$ and this skepticism extends even to his philosophical anthropology and moral theory. ${ }^{8}$ Ideas were, for him, but faint imitation of sensations. ${ }^{9}$ Not only was he skeptical about reason, he was likewise fiercely opposed to any notion of theological or religious ethics ${ }^{10}$ notwithstanding his strong Calvinist background. ${ }^{11}$ He thought of human action as a composite of passions, sentiments and volitions and not as exercise of some rational nature. ${ }^{12}$ His famous dichotomy between is and ought ${ }^{13}$ as well as his rejection of an essentialist notion of human identity ${ }^{14}$ radically changed the grammar of ethical theory and definitively secured his legacy way beyond his own generation. MacIntyre traced to Hume the germination of theoretical

\footnotetext{
${ }^{5}$ Frederick Beiser, "The Enlightenment and Idealism" in The Cambridge Companion to German Idealism, ed. by Karl Ameriks (Cambridge: Cambridge University Press, 2005), 19.

${ }^{6}$ Alasdair MacIntyre, Whose Justice? Which Rationality? (Indiana: University of Notre Dame Press, 1988) 281-299.

${ }^{7}$ See David Hume, "Book I, Part IV, Section I: Of skepticism with regard to reason," in A Treatise of Human Nature (London: John Noon, 1739), 180-181. See also Claudia M. Schmidt, David Hume: Reason in History (Pennsylvania: The University of Pennsylvania Press, 2003), 137160 .

${ }^{8}$ Hume, "Book III, Part I, Section I: Moral Distinction not deriv'd from reason," in $A$ Treatise of Human Nature, 457.

9 David Hume, An Enquiry Concerning Human Understanding, ed. by Tom L. Beauchamp (Oxford: Oxford University Press, 1999), 97.

${ }^{10}$ David Hume, "Section XIV: Bad Influence of Popular Religions on Morality," in The Natural History of Religion in The Philosophical Works of David Hume, vol. 4 (London: Charles Tait, 1826), 508.

${ }_{11}$ David Hume, Dialogues Concerning Natural Religion, ed. by Norman Kemp Smith (New York: The Bobbs-Merrill Company, Inc., 1947), 1-8.

${ }^{12}$ Hume, "Book III, Part I, Section I: Moral Distinctions not deriv'd from reason," in $A$ Treatise of Human Nature, 458.

${ }^{13}$ Ibid., 469-470.

${ }^{14}$ Hume, "Book I, Part IV, Section VI: On Personal Identity," in A Treatise of Human Nature, 259-260. See also Hume, "Book I, Part I, Section V: Of relations," in A Treatise of Human Nature, 16.
} 


\section{MACINTYRE AND THE TENSION WITHIN THOMISM}

elements that would later find its way to G.E. Moore ${ }^{15}$ and Charles Stevenson ${ }^{16}$ in their respective versions of emotivist theory. ${ }^{17}$ The avant-garde philosopher Gilles Deleuze also turned to Hume for the framework of his own counter philosophical anthropology. ${ }^{18}$ And as one would read in Charles Taylor ${ }^{19}$ and Ruth Groff, ${ }^{20}$ even the alleged metaphysical neutrality professed by liberal theorists like John Rawls bore traces which harked back to the position introduced by Hume. ${ }^{21}$

Another fierce critic of reason was Jean-Jacques Rousseau, himself an illustrious member of a group of intellectuals behind the French Enlightenment. Rousseau was a contributor to Diderot's encyclopedia but it wouldn't be until his essay, Discourse on the Arts and Sciences won the Académie de Dijon's top prize, that he would gain larger public recognition. The contest's theme was on the development of the arts and sciences and its impact on the society's moral growth. Rousseau's verdict did not speak well of the arts and sciences but the acclaim of his essay certainly put his career in a good light. ${ }^{22}$ In a much longer work, his didactic literary opus Emile, ${ }^{23}$ more pointedly advanced his devaluation of reason, including the established religion and in their place. Here, he commended his main character Emile to turn his attention to the cultivation of his conscience. Given the fact the society in general is degenerate, Emile had nowhere to turn to but himself $\grave{a}$ la Robinson Crusoe. ${ }^{24}$ Emile needed to arm himself with an education suitable enough to protect him from the worsening moral corruption. Rousseau dispensed his prescription for a new moral education via a story narrated to

${ }^{15}$ See G.E. Moore, Principia Ethica (New York: Prometheus Books, 1988).

16 See Charles L. Stevenson, Ethics and Language (New Haven: Yale University Press, 1958).

${ }^{17}$ MacIntyre, After Virtue, 14.

18 See Gilles Deleuze, Empiricism and Subjectivity: An Essay on Hume's Theory of Human Nature, trans. by Constantin Boundas (New York: Columbia University Press, 1991); Jeffrey Bell, Deleuze's Hume: Philosophy, Culture and the Scottish Enlightenment (Edinburgh: Edinburgh University Press, 2009).

${ }^{19}$ Charles Taylor, Philosophy and the Human Sciences: Philosophical Papers 2 (Cambridge: Cambridge University Press, 1985), 60.

${ }^{20}$ Ruth Groff, Ontology Revisited: Metaphysics in Social and Political Philosophy (London: Routledge, 2014), 1.

${ }^{21}$ John Rawls, Political Liberalism, expanded edition (New York: Columbia University Press, 2005), 9-10.

${ }^{22}$ Jean-Jacques Rousseau, The Discourses and Other Early Political Writings, ed. by Viktor Gourevitch (Cambridge: Cambridge University Press, 1997), 9.

${ }^{23}$ Emile is often mistakenly classified as a novel. This should not be confused with the novel authored by Rousseau entitled, La Nouvelle Héloïse: Julie, or the New Eloise. See Jean-Jacques Rousseau, La Nouvelle Héloïse: Julie, or the New Eloise: Letters of Two Lovers, Inhabitants of a Small Town at the Foot of the Alps, trans. by Judith H. McDowell (Pennsylvania: The Pennsylvania State University Press, 1987).

${ }^{24}$ Jean-Jacques Rousseau, Emile or on Education, trans. by Allan Bloom (USA: Basic Books, 1979), 184-185, 208.

(C) 2016 Jovito V. Cariño

http://www.kritike.org/journal/issue 19/carino december2016.pdf

ISSN 1908-7330

(c) ) BY-NC-ND 
Emile by his tutor about a certain Savoyard Vicar. ${ }^{25}$ Emile may be comparable with Aristotle's Nicomachean Ethics or Plato's The Republic in its motif, though Rousseau would have none of the privileged role that either Plato or Aristotle assigned to reason. ${ }^{26}$ On its own however, it was widely considered as a philosophical milestone for its ability to argue for religion without appeal to divine revelation and to lay the foundation for what is considered today as a post-Christian civilization. ${ }^{27}$ If there is any revelation with which God had disclosed himself to humanity, it was none other than his own selfaffirmation reposed in the heart of each human person. ${ }^{28}$ Such benign though romantic view of human nature can also be found in his other work, Discourse On The Origin and Foundations of Inequality Among Men. ${ }^{29}$ It was such romantic bent plus his critical stance on reason that put him at odds with his fellow French Enlightenment thinker and literary figure, Voltaire. Together with Maupertuis and d'Alembert, Voltaire pursued instead the scientific path of Enlightenment charted by Isaac Newton. ${ }^{30}$ French thinkers considered Newton as the premiere exponent of the new mode of thinking which allowed them to come to terms with the complexities of the physical world and at the same time explore ways of expanding further such knowledge. ${ }^{31}$

These were the two poles, reason as a faculty of criticism and reason as power of explanation, which dominated the philosophical debates of the Enlightenment period, two epistemic positions which, ironically, when stretched to their limits could undermine the very integrity of human knowledge itself. Criticism when overdone could lead to skepticism; too much dependence on mathematical explanation could inadvertently end up with materialism. The two were the distant islands through which Immanuel Kant navigated his way when he decided to intervene in the contest which attracted the best minds of the $18^{\text {th }}$ century Europe.

\footnotetext{
${ }^{25}$ Ibid., 262.

${ }^{26}$ Ibid., 212; see also Ibid., 243-244; 268-269; 278-279.

${ }_{27}$ Ibid., 255-260, 277-278; see also Mark Lilla, The Stillborn God: Religion, Politics and the Modern West (New York: Random House 2008), 115.

${ }^{28}$ Ibid., 295.

${ }^{29}$ Rousseau, "Part I" of "Discourse on the Origin and Foundations of Inequality Among Men," in The Discourses and Other Early Political Writings, 151.

${ }^{30}$ Ernst Cassirer, The Philosophy of the Enlightenment, trans. by Fritz C.A. Koelln and James P. Pettegrove (Boston: Beacon Press, 1951), 55.

${ }^{31}$ Isaac Newton, Author's Preface to "The Principia [1687, first edition]" in Philosophical Writings, ed. by Andrew Janiak (Cambridge: Cambridge University Press, 2004), 41. See Thomas L. Hankins, Science and the Enlightenment (Cambridge: Cambridge University Press, 1985), 17-45; J.B. Shank, The Newton Wars and The Beginning of The French Enlightenment, (Chicago: The University of Chicago Press, 2008), 37-48.
} 
196 MACINTYRE AND THE TENSION WITHIN THOMISM

\section{Re-stating the Supremacy of Reason: The Kantian Position}

It was no coincidence that, in his subsequent writings, Kant would invoke the names of Hume ${ }^{32}$ and Rousseau ${ }^{33}$ as two of his biggest influences. The title of Kant's first major work, Critique of Pure Reason, might suggest that he had already taken side, but a perusal of the text would tell us differently. Kant did not really wish to restore critique to the function of reason; on the contrary, he wanted to subject reason to a thorough critique for only then can reason presume to deconstruct or explain any aspect of reality. ${ }^{34}$ Unless this is done carefully and judiciously, all the critiquing and all the explaining will eventually exhaust reason itself until there will be nothing left worth knowing. ${ }^{35}$ Until this point, one might still suspect Kant as taking the cudgels for reason. In fact, most readers considered the Critique and Kant's Copernican revolution as an epistemological tour de force. And yet one only needs to consult the prior and posterior parts of the Critique to see where Kant really stands as far reason is concerned. ${ }^{36}$ This is why I consider Kant as pivotal in the discussion of the modern rupture between faith and reason, due to the very important claims he made in this book concerning the matter. Between Hume and Rousseau, it is important to state that it was Rousseau's side that Kant upheld when he asserted that the whole purpose of human reason is not really to know the world but to change and transcend it through ethical action and it was this ethical aspect of reason that would lead Kant to reason's religious dimension. ${ }^{37}$ Bertrand Russell would say that for Kant, Hume was an adversary to be refuted whereas Rousseau was a sympathetic mind. ${ }^{38}$ Notwithstanding his reverence for Rousseau, however, who, incidentally, was the only author powerful enough to interrupt his afternoon promenades, Kant had misgivings on the role of sentiments in the former's moral religion, and he knew, that left on their own, a moral vision grounded on sentiments could easily flounder. ${ }^{39}$ Convinced of how badly it needed a stronger foundation, Kant tried to re-instate Rousseau's moral campaign in a

32 Immanuel Kant, Kant's Prolegomena to Any Future Metaphysics, ed. by Paul Carus (Chicago: Open Court Publishing Company, 1912), 7.

${ }^{33}$ Immanuel Kant, Observations on the Feeling of the Beautiful and Sublime and Other Writings, ed. by Patrick Frierson and Paul Guyer (Cambridge: Cambridge University Press, 2011), 96.

${ }^{34}$ Immanuel Kant, Preface to the First Edition of Critique of Pure Reason, trans. by Marcus Weigelt. (London: Penguin Books, 2007), 593.

${ }^{35}$ Ibid., 601.

36 Ibid., 25, 637.

${ }_{37}$ Clifford Orwin and Nathan Tarcov, eds., The Legacy of Rousseau (Chicago: The University of Chicago Press, 1997), 54.

${ }^{38}$ Bertrand Russell, History of Western Philosophy (London: Taylor \& Francis Group, 2005), 640 .

${ }^{39}$ Lilla, The Stillborn God, 133.

(C) 2016 Jovito V. Cariño

http://www.kritike.org/journal/issue 19/carino december2016.pdf

ISSN 1908-7330

(c) $)$ BY-NC-ND 
more solid rational grounding, a portion of an account of which Kant had already intimated in his first Critique. Kant was aware of reason's own inadequacies (case in point, the paralogisms and aporias as cited by Kant) and the Critique was meant to highlight what it could and could not do before reason begins a new task. Turning away from Hobbes and Locke, both of whom considered reason as a passive principle, Kant maintained that reason was by nature architectonic, that is, it had the capacity to devise a system to aid itself in the determination of knowledge. ${ }^{40}$ Hence, for Kant, reason must be distinguished from understanding, the faculty responsible for the unity of appearances under certain rules whose unity, reason in turn provides. ${ }^{41}$ It is reason that presides over the so-called regulative ideas, namely: self, world, and God. Not one of these three has objective reality for Kant; these are mere ideas posited "problematically" for the sake of the unity they provide in human perception. ${ }^{42}$ Kant's position is of course a radical departure from the conjunction between man, nature and God perceived by the pre-modern thinking as objectively real. What we see here is a careful reconfiguration being done by Kant concerning the unity of reason and faith, a reconfiguration which also tries to go beyond the traditional physicotheological, cosmological, and ontological proofs of God's existence. ${ }^{43}$ What then does it mean to consider God as a regulative idea? It means that the highest faculty of man, that is reason, considers the existence of God as the "purposive unity of things," which means that the systematic unity of all things would not have been apprehensible were it not derived from God himself. ${ }^{44} \mathrm{Up}$ to this point, it appears as if Kant is merely rehashing the Thomistic argument of design of creation. This is, however, farthest from Kant's point, for as he explained, God as a regulative idea, while presupposed as a priori, is nonetheless not necessarily considered as the "the ground of all things," hence the qualification is regulative rather than constitutive. ${ }^{45}$ Whereas Hobbes considered fear as the origin of religion and Rousseau thought of it as engendered by sentiments, Kant made it utterly inescapable and secure in its foundation by locating its source in reason itself. Once more, it appears as though one will find a stronger argument for the unity of faith and reason in Kant rather than its rupture. Yet, if this is true, then Hegel would have labored in vain trying to recover the unity between the two, ${ }^{46}$ not

${ }^{40}$ Kant, Critique of Pure Reason, 426.

${ }^{41}$ Ibid., 291.

${ }^{42}$ Ibid., 556, 557-561.

${ }^{43}$ Ibid., 499.

${ }^{44}$ Ibid., 560.

${ }^{45} \mathrm{Ibid} ., 564$.

${ }^{46}$ Hegel did not think that God was part of the reason's architectonic nor religion restricted to the exercise of reason. Religion was a shared experience embedded in a given a culture and the consciousness of God was part of the evolution of history. In such evolution, 
to mention the efforts of such thinkers like Friedrich Schleiermacher ${ }^{47}$ and theologians like Karl Barth and Franz Rozenweig who until the twentieth century were trying to confront Kant's transposition of religion into the architectonic of reason..$^{48}$ In truth, the appearance of conjunction between faith and reason in Kant is only an appearance which resulted from Kant's rigid confinement of everything within his self-contained system. As indicated above, reason for Kant is pure subjectivity. Unlike the pre-modern notion of reason which admitted of subject-object relation, such relation was nullified in Kant, having rejected the possibility of objectivity be it in the form of self, world, or God himself. With his rejection of objectivity, Kant likewise decided against the possibility of truth, much less truth that does not conform with the regulations of reason. It is on this account that Kant was able to assert that the only way for belief to bear on anything at all was for him to suspend the operation of reason. Faith has its dynamism, its own vitality, its origin, and telos which lay beyond the scope of reason. With only the transcendental forms of thought to deal with, reason as it was conceived by Kant, is illequipped to deal with anything so completely alien to it. Kant's moral, that is, rational religion, might include religion in its name but it has none of the elements of faith the way it is traditionally understood. The only way for that kind of faith and reason to work together from the Kantian perspective is for them to stay apart. Reason cannot accommodate traditional faith; neither can the same faith engage reason. Reason, however, can motivate action and it is in that domain that Kant wishes to give religion its new foundation. ${ }^{49} \mathrm{It}$ is true that Kant mentioned faith in his second Critique but he did so merely to emphasize its being a postulate of reason and how, by virtue of such

religion precedes philosophy but such evolutionary priority did not negate the symbiotic relationship between the two. As Hegel pointed out: "Thus philosophy is theology, and (one's) occupation with philosophy - or rather in philosophy - is of itself the service of God." See G.W.F. Hegel, Lectures on the Philosophy of Religion: Volume I, Introduction and Concept of Religion, ed. by Peter C. Hodgson, trans. by R.F. Brown, P.C. Hodgson, and J.M. Stewart (Berkeley: University of California Press, 1984), 84; see also G.W.F. Hegel. Phenomenology of Spirit, trans. A.V. Miller (Oxford: Oxford University Press, 1977), 416; G.W.F. Hegel, On Christianity: Early Theological Writings, trans. T.M. Knox (New York: Harper Torchbooks, 1961), 145-158.

${ }^{47}$ Friedrich Schleiermacher, On Religion: Speeches to its Cultural Despisers, trans. and ed. by Richard Crouter (Cambridge: Cambridge University Press, 2003), 25-26.

${ }^{48}$ Both Rosenzweig and Barth, in their respective works, strived to restore religion to their distinct character, that is, outside its confinement within categories of reason. Rozenweig, a Jewish theologian, together with Barth, a Protestant theologian, were convinced that faith could only be revivified through the recovery of its roots in revelation. See Karl Barth, The Epistle to the Romans, trans. by E.C. Hoskyns (Oxford: Oxford University Press, 1968), 35. See also Franz Rozenweig, The Star of Redemption, trans. by Barbara E. Galli (Wisconsin: The University of Wisconsin Press, 2005), 31.

${ }^{49}$ Immanuel Kant, "What Does It Mean to Orient Oneself in Thinking?" in Religion within the Boundaries of Mere Reason and Other Writings, ed. and trans. by Allen Wood \& George di Giovanni (Cambridge: Cambridge University Press, 1998), 10.

(c) 2016 Jovito V. Cariño

http://www.kritike.org/journal/issue 19/carino december2016.pdf

ISSN 1908-7330

(cc) BY-NC-ND 
postulation, it is accommodated merely to make the whole Kantian ethical system work. ${ }^{50}$

\section{Between Aquinas and Kant: An Illustration of Tradition- constituted Rationality}

Up to this point, one can find a certain degree of parallelism between Kant and Thomas' views on the role of faith. Both of them believed that faith should be oriented to the good that must be attained by ethical agent and both affirmed the important function of the will in the exercise of such faith. The parallelism however automatically ceases when one begins to consider that for Thomas, will is a faculty directed towards an object beyond oneself and that good is an end that is desired likewise beyond oneself. Moreso, faith for Thomas is not just a postulate of reason but a virtue that exceeds reason itself. ${ }^{51}$ In contrast, will for Kant pertains to reason's power to create and pursue its own objects ${ }^{52}$ and that the good he considers is an end which requires merely formal satisfaction and nothing else. ${ }^{53}$ His commitments to his critical philosophy prevented him from ever going beyond reason's own forms and principles; Thomas' adherence to metaphysical realism however made him more attentive to the inherent limitations of reason. This fundamental difference between Kant and Thomas Aquinas is important to bear in mind particularly in considering the relation between faith and reason which Kant negated and Thomas affirmed. It also provides a significant background against which one may read the variety of Thomistic responses to the problems posed by modernity concerning faith and reason. As shown in the preceding discussion, faith and reason for Thomas are not just two distinct domains; they are also two distinct traditions represented by Augustine (faith) on one hand and Aristotle (reason) on the other. In the context of Thomistic discourse, when one thinks of the unity of faith and reason, one situates the two in a fruitful dialogue. When two traditions confront each other, inevitably, an epistemological crisis will ensue.

${ }^{50}$ Immanuel Kant, Critique of Practical Reason, trans. by Werner S. Pluhar (Indiana: Hackett Publishing Co., Inc. 2002), 160.

51 Thomas Aquinas, Questionaes Disputatae de Veritate in St. Thomas' Works in English (Dominican House of Studies: Priory of the Immaculate Conception), <http://dhspriory.org/thomas/QDdeVer14.htm>. 14.2 ad 1-10. Thomas Aquinas, Summa Theologica in St. Thomas' Works in English (Dominican House of Studies: Priory of the Immaculate Conception), <http://dhspriory.org/thomas/summa/SS/SS004.html\#SSQ4OUTP1>, II-II, 4.1. Thomas Aquinas, Super Boethium de Trinitate in St. Thomas' Works in English (Dominican House of Studies: Priory of the Immaculate Conception) <http://dhspriory.org/thomas/BoethiusDeTr.htm $>$, 3.1, ad $1-5$.

${ }^{52}$ Kant, Critique of Practical Reason, 23.

53 See Kant, Preface to the First Edition of "Religion Within the Boundaries of Mere Reason," in Religion Within the Boundaries of Mere Reason and Other Writings, 34. 
According to MacIntyre, an epistemological crisis happens when an individual, an institution, or a community begins looking for a justification for what it has been doing or what it has always known in the face of a new development which presents itself as a challenge or an alternative to the current state of affairs. To illustrate his point, MacIntyre cites the experience of Shakespeare's Hamlet who, upon return from Wittenberg, found himself at a loss as to which course of action he needed to take given his discovery of the events waiting for him at Elsinore. It was the same situation Maria Clara had found herself in, after reading her late mother's old letters for which she exchanged the lone letter she received from Ibarra. The surprise and anxiety that came with the revelation of her true origins gravely unsettled Maria Clara thus rendering her old "schemata" practically useless. In a larger scale, MacIntyre also invoked the experience of Galileo. At the start of his career, Galileo found himself in the middle of conflicting scientific interpretations between Ptolemy and Copernicus. The theories of Ptolemy, the acknowledged authority of the science of antiquity, were being severely challenged by the studies and findings done by Copernicus, the emerging leading figure of modern science. Galileo's situation was an example of an epistemological crisis at its thorniest. Bur rather than merely dumping one in favor of the other, what Galileo did was to draw a narrative which provided a context for both and allowed him to evaluate them using a set of standards applicable to either tradition. With such narrative, Galileo in effect restored both traditions in their proper places via his recourse to a single rendition, while at the same time, creating a space for further scientific inquiry. ${ }^{54}$ In all his works, in particular, his Summa Theologica, Thomas Aquinas showed close affinity with the tact that Galileo had undertaken. One might read the Summa then as a narrative that integrated two competing traditions, Augustinianism and Aristotelianism. At the same time, they are evaluated using rubrics useful for both, and as long as the evaluation is maintained, the possibility of enhancement or refutation from future inquiry will always remain open. What was lost in most modern philosophies, said Macintyre, was such sense of narrative and such sense of integrative evaluation. ${ }^{55}$ An apt illustration of this is Descartes' own description of his epistemological crisis. Such crisis, if one goes back to Descartes' account in the Meditations, was homegrown or sui generis. It didn't stem from any encounter with a rival system or shared

54 Alasdair MacIntyre, "Epistemological Crises, Dramatic Narrative, and the Philosophy of Science," in The Tasks of Philosophy: Selected Essays, vol. I (Cambridge: Cambridge University Press, 2006), 3-23.

${ }^{55}$ MacIntyre writes: "But the history of epistemology, like the history of ethics itself, is usually written as though it were not a moral narrative, that is, in fact as though, it were not a narrative. For a narrative requires an evaluative framework in which good or bad character helps to produce unfortunate or happy outcomes." See Ibid., 6 .

(C) 2016 Jovito V. Cariño

http://www.kritike.org/journal/issue 19/carino december2016.pdf

ISSN 1908-7330

(c) BY-NC-ND 
practice but from his own cogitation. To borrow MacIntyre's expression, it was a crisis without a tradition. The absence of such tradition however was neither accidental nor gratuitous. It was not taken into account simply because Descartes took it for granted-convinced that he would overcome his epistemological crisis if he starts from some presuppositionless first principle. ${ }^{56}$ Another illustrative example of the same point would be the project of Kant. It was clear from the start that Kant wanted to steer clear of the metaphysical tradition, in particular from Aristotle. With his debunking after debunking of all the traces of the philosophical tradition that bred him, Kant was left with nothing but the regulative principles of knowledge to which were known nothing but the regulative principles themselves. If ever Kant attempted to integrate Aristotle in his narrative of his own epistemological crisis, it was to ridicule him or downplay his contribution to philosophy. In the Preface to the First Edition of the first Critique, he ascribed the roots of the dogmatic tendency of rationalism to the sway of metaphysics. ${ }^{57}$ Then in the Preface to the Second Edition, he also declared that ditching the speculative reason would not make such a loss, for it was by "no means the interest of humanity." 58 Probably the clearest indication of Kant's distanciation from Aristotle could be found in Section III, Book I of the Second Part of his discussion of the Transcendental Doctrine of Elements. It was here that Kant set aside the categories of Aristotle in favor of the superiority of his own, saying: "It was an enterprise worthy of an acute thinker like Aristotle to try to discover these fundamental concepts but as he had no guiding principle he merely picked them up as they occurred to him and at first gathered up ten of them which he called categories." 59 Kant maintained that his categories had the edge compared to their Aristotelian counterparts since his "classification has been generated systematically from a common principle, namely the faculty of judging (which is the same as our faculty of thinking). It has not arisen rhapsodically as the result of a search after pure concepts ..." 60 Another indirect though substantial attack on Aristotelian positions was undertaken by Kant in his discussion of Transcendental Dialectic where he deconstructed the faculty of reason as it was known from Aristotle and exposed the illusions generated by it. ${ }^{61}$ Kant says that, as far as pure reason is concerned, "we can have no knowledge of an object corresponding to an idea but only a problematic concept of it." 62 The most that one can say about the

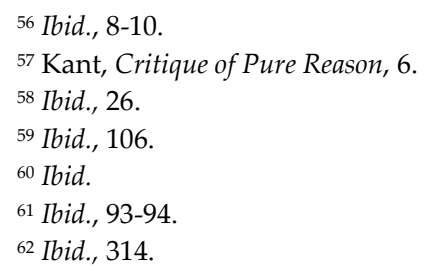


so-called highest syntheses about substance, world, and the self, namely God, freedom and immortality are but paralogisms, antinomies, and ideals of pure reason. Contrary to the Aristotelian positions, Kant would say we can never arrive at certainty regarding these matters. All we can ever hope are arguments that are mutually exclusive and directly antithetical in their truth claims. When MacIntyre described the Enlightenment as the repudiation of Aristotle, he had in mind not only the philosopher as individual but the entire tradition of rationality which he represented and from which modernity chose to distance itself. ${ }^{63}$ Enlightenment dismissed a rationality that was narrative, evaluative, tradition-constituted as well as tradition-constitutive. The directs heirs of the Enlightenment legacy were the two schools of inquiry dominant during the nineteenth century which MacIntyre described as the encyclopaedists and the genealogists. The encyclopaedists, best represented by Adam Gifford, the progenitor of the famous Gifford Lectures and the editors and contributors of the Ninth Edition of the Encyclopedia Britannica published in the late nineteenth century, ${ }^{64}$ believed that the history of philosophy followed a continuous evolution whose apex is reached with the development of reason into a universal claim, that is, free from any tradition. ${ }^{65}$ The genealogists, on the other hand, counting Nietzsche as its prime exponent, likewise believed in an uninterrupted flow of the history of philosophy except that it did not see it as culminating into the full development of reason into a universal claim the way the encyclopaedists thought it would. ${ }^{66}$ For the genealogists, the history of philosophy is indeed continuous but only as a showcase of a series of distortion or frustration of the will-to-power. ${ }^{67}$ It was in response to these two conflicting interpretations of history of philosophy that modern Thomism became a participant of the debate through the writings of the Jesuit priest Joseph Kleutgen, who as it turned out, would play a vital role in the modern revival of Thomism.

\section{Reviving Thomism: The Tension Within}

Born in Dortmund, Germany on April 10, 1811, Kleutgen later on attended the University of Munster and the University of Paderborn and consequently proved himself to be a formidable intellectual following his ordination as a Jesuit priest in 1837. He was a professor of philosophy and

\footnotetext{
${ }^{63}$ MacIntyre, After Virtue, 81.

${ }^{64}$ Alasdair MacIntyre, Three Rival Versions of Moral Enquiry: Encyclopedia, Genealogy and Tradition (Indiana: University of Notre Dame Press, 1990), p.18.

65 Ibid., 65.

${ }^{66}$ Ibid., 59.

${ }^{67}$ Ibid., 58. 
rhetoric in Freiburg and Brig, Switzerland respectively before he was appointed consultor of the Congregation of the Index in Rome, official at the General Curia of the Society of Jesus, and prefect of studies at the Gregorian University. Among Kleutgen's significant credits included the voluminous Appendices to the Works on the Old Theology and Philosophy published in 1858 as well as the draft of the Dogmatic Constitution on the Catholic Faith which he co-authored with Johannes Baptist Franzelin and adopted by the First Vatican Council in 1870.68

It was at Freiburg that Kleutgen developed interest on preEnlightenment thinkers, chief among them Thomas Aquinas. He was convinced that the problem of the disjunction between faith and reason so prevalent among Enlightenment thinkers could be solved if modern philosophy were set aside and the philosophy of the earlier ages were revived. ${ }^{69}$ Kleutgen finally got the chance to realize his project with the publication of his first published work against the Enlightenment, Über die alten und die neuen Schulen. ${ }^{70}$ It was in this book that he concretized his call for the restoration of medieval philosophy and the utter repudiation of the modern system of thought. Among the scholastics, Kleutgen singled out Thomas Aquinas as the greatest of them all. ${ }^{71}$ It was on this account that, in MacIntyre's reading, Kleutgen's position presented itself as an alternative to the dominant views of the encyclopaedists and the genealogists. Unlike the two camps, Kleutgen found in the history of philosophy a radical break instead of continuity. He situated that break between the philosophy which evolved from Socrates to Thomas, and such philosophy which considered

\footnotetext{
${ }^{68}$ Gerald A. McCool, Nineteenth Century Scholasticism: The Search for a Unitary Method (New York: Fordham University Press, 1989), 175-176.

${ }^{69}$ In a letter to his former teacher, Kleutgen writes: “For you know that I most definitely think that one should be familiar with the philosophy of former centuries in order to oppose the bad direction of the philosophy in our century, and that one has to investigate very well the relation between contemporary philosophy, which has brought disbelief into almost science and art as well as into life, and the older philosophy, which for so long has happily defended the faith." Kleutgen quoted in John Inglis, Spheres of Philosophical Inquiry and the Historiography of Medieval Philosophy (The Netherlands: Brill, 1998), 70.

${ }^{70}$ Ibid., 72.

${ }^{71}$ Inglis writes: "The type of philosophy to which, Kleugen argues, we should return is the type taught for centuries by Dominicans, Francisicans, Jesuits, and other religious orders in the institutions that had been lost through secularization. His point is that, if we are gping to make any progress, we must rebuild these institutions, as well as the promote the work of Aquinas. Kleutgen argues that Aquinas is the greatest of the Scholastics because he offers a correct account of the relation between reason and revelation. But Kleutgen does not provide the justification for his claim that Aquinas solves the problem of reason and revelation. He does not explain Aquinas's solution. Rather, he puts out a call for research into the study of medieval thought in order to oppose the influence of modern Protestant philosophy." See Inglis, Spheres of Philosophical Inquiry and the Historiography of Medieval Philosophy, 73.
} 
Descartes as its originator. ${ }^{72}$ Before Kleutgen, however, there have been other attempts by Catholic thinkers to combat the challenges to the Catholic thought posed by the Enlightenment. On top of the list would be the name of Antonio Rosmini who, together with other Catholic thinkers, made earnest efforts to reconcile Catholic faith with modern epistemology but ended up capitulating the Catholic realist position to modern epistemological categories. ${ }^{73}$ Kleutgen wanted to avoid his route by declaring a clean break between the old and the modern philosophies. What weakened his position however was his identification of where such break was located. For instead of putting the discontinuity between Thomas and his immediate successors, Kleutgen marked it off quite belatedly, that is, in the later Scholasticism, hence his failure to make the distinction between the positions of Thomas and those of his early modern followers like another Thomist Jesuit, Francisco Suarez. This intellectual lapse on the part of Kleutgen would bear a serious impact on the definition of Thomism in relation with modernism. Because Suarez did not have any inkling on the kind of inquiry which Thomas employed to overcome the limitations of both Augustinianism and Aristotelianism, he, and so did Kleutgen later on, thought that what he had presented in his works was his final statement on the inadequacies of a single rather than two contesting, limited traditions. MacIntyre cited as an example, the great disparity between Thomas' handling of the articles of the first five questions of Quaestiones Disputatae de Veritatae and Kleutgen's interpretation of the same. While Thomas' account combined a series of descriptions, analyses, and clarifications that left the door open for further consideration, Kleutgen read it as tightly sealed justification for the existence of truth. In doing so, Kleutgen unknowingly mistook Thomas' position for that of Suarez for whom apprehension of truth was dependent upon universal concepts which the mind itself fashions prior to such apprehension. ${ }^{74}$ With such dependence on epistemic concepts, the existence of entities outside the mind became an open question, and hence, bestowing to Thomas, in particular, to De Veritate, an epistemological concern that was nowhere in existence in his system. This was then the kind of interpretation of Thomas which would be

72 MacIntyre, Three Rival Versions of Moral Enquiry, 59.

${ }^{73}$ A discussion of Antonio Rosmini-Serbati may be found in Alasdair MacIntyre, God, Philosophy, Universities: A Selective History of the Catholic Philosophic Tradition (London: rowman and Littlefield Publishers Inc., 2009), 133.

${ }^{74}$ Daniel D. Novotny, Beings of Reason: A Study in Scholasticism of the Baroque Era (Ph.D. Dissertation, New York: State University of New York, 2008), 69; see also, MacIntyre, Three Rival Versions of Moral Enquiry, 74. For a more elaborate discussion see, Jan A. Aertsen, "The 'Metaphysical Disputations' of Francisco Suarez: Between Scholasticism and Modernity," in Medieval Philosophy as Transcendental Thought: From Philip The Chancellor (ca 1225) to Francisco Suarez (The Netherlands: Brill, 2012), 587-634; see also Jose Pereira, Suarez: Between Scholasticism and Modernity (Wisconsin: Marquette University Press, 2006), 141-224.

(c) 2016 Jovito V. Cariño

http://www.kritike.org/journal/issue 19/carino december2016.pdf ISSN 1908-7330

(c) BY-NC-ND 
brought to bear on Aeterni Patris ${ }^{75}$ whose formulation, according to experts, was greatly influenced by Kleutgen himself. ${ }^{76}$ The continuous epistemological conversion of Thomas' philosophy would be further escalated by succeeding generations of thinkers, in particular, by another Jesuit priest, Joseph Marechal, who thought of Thomas as the court of appeal to the questions which Kant himself failed to resolve. ${ }^{77}$ Marechal was strongly opposed by Etienne Gilson ${ }^{78}$ although he found an ally in Jacques Maritain who likewise displayed transcendental leanings in his rendition of Thomistic philosophy. ${ }^{79}$

\section{Conclusion}

The foregoing discussion was meant to illustrate my earlier claim that Thomism itself was implicated in modernism and neglect of this crucial fact somehow weakened the position of the Thomist campaign against the philosophical and cultural tendencies it wished to moderate. Without Thomas wanting it, the zeal of the succeeding Thomists to present him as the paragon of thinking where faith and reason find its distinct harmony prevented them from taking into consideration the tradition of inquiry he himself fostered in his engagement with rival traditions during his time. In MacIntyre's account, it was this sort of inquiry that gave rationality, from the perspective of Thomas, the aspect of being tradition-constituted and tradition-constitutive. Its appeal to both traditions so as to render both their strengths and weaknesses intelligible via a synthetic narrative that is reflective and evaluative of both made it tradition-constituted. Its ability however to point a new path along which new answers and new questions may be pursued made it tradition-constitutive. This was the aspect of Thomas' philosophy that Aeterni Patris failed to acknowledge. The result, as MacIntyre lamented, was the emergence of many Thomisms trapped in the same epistemic quandary they were all trying to transcend. Even Aeterni Patris, with its espousal of Thomism as a concluded system against which all systems must justify themselves, failed to overcome the very problems for which it thought it had the answers. Rather than forging back the unity between faith and reason, such failure in fact contributed to the vanishing of

${ }^{75}$ Leo XIII, “Aeterni Patris: Encyclical of Pope Leo XIII on the Restoration of Christian Philosophy," in The Holy See (4 August 1879), < $\underline{\text { https://w2.vatican.va/content/leo- }}$ xiii/en/encyclicals/documents/hf l-xiii enc 04081879 aeterni-patris.html $>$.

${ }^{76}$ MacIntyre, Three Rival Versions of Moral Enquiry, 73; see also McCool, Nineteenth Century Scholasticism, 167.

77 MacIntyre, Three Rival Versions of Moral Enquiry, 76; see also MacIntyre, God, Philosophy, Universities, 154.

${ }^{78}$ McCool, Nineteenth Century Scholasticism, 256

${ }^{79}$ MacIntyre, Three Rival Versions of Moral Enquiry, 76. 


\section{MACINTYRE AND THE TENSION WITHIN THOMISM}

the unity of faith and reason as a human concern. It was Weber who used the word "disenchantment" to describe situation of the modern man who, suffused with the new discoveries of modern knowledge, got his sense of faith sidetracked in the process. Where then does it leave man and human flourishing? This is the kind of question that makes the rethinking of Catholic philosophy in the guise of Thomism a perennial undertaking.

Department of Philosophy, University of Santo Tomas, Philippines

\section{References}

Aertsen, Jan A, Medieval Philosophy as Transcendental Thought: From Philip The Chancellor (ca 1225) to Francisco Suarez (The Netherlands: Brill, 2012).

Ameriks, Karl, ed., The Cambridge Companion to German Idealism (Cambridge: Cambridge University Press, 2005).

Aquinas, Thomas, Super Boethium de Trinitate in St. Thomas' Works in English (Dominican House of Studies: Priory of the Immaculate Conception) $<$ http://dhspriory.org/thomas/BoethiusDeTr.htm>.

Summa Theologica in St. Thomas' Works in English (Dominican House of Studies: Priory of the Immaculate Conception), $<$ http://dhspriory.org/thomas/summa/SS/SS004.html\#SSQ4OUTP1>.

Questionaes Disputatae de Veritate in St. Thomas' Works in English (Dominican House of Studies: Priory of the Immaculate Conception), $<$ http://dhspriory.org/thomas/QDdeVer14.htm $>$.

Barth, Karl, The Epistle to the Romans, trans. by E.C. Hoskyns (Oxford: Oxford University Press, 1968).

Beiser, Frederick, "The Enlightenment and idealism," in The Cambridge Companion to German Idealism, ed. by Karl Ameriks (Cambridge: Cambridge University Press, 2005).

Bell, Jeffrey, Deleuze's Hume: Philosophy, Culture and the Scottish Enlightenment. (Edinburgh: Edinburgh University Press, 2009).

Brown, Stuart, ed., British Philosophy and The Age of Enlightenment (New York: Routledge, 1996).

Cassirer, Ernst, The Philosophy of the Enlightenment, trans. by Fritz C.A. Koelln and James P. Pettegrove (Boston: Beacon Press, 1951).

D'Alembert, Jean Le Rond, Preliminary Discourse to the Encyclopedia of Diderot, trans. by Richard N. Schwab (Chicago: University of Chicago Press, 1995).

Deleuze, Gilles, Empiricism and Subjectivity: An Essay on Hume's Theory of Human Nature, trans. by Constantin Boundas (New York: Columbia University Press, 1991).

(c) 2016 Jovito V. Cariño

http://www.kritike.org/journal/issue 19/carino december2016.pdf

ISSN 1908-7330

(c) $)$ BY-NC-ND 
Groff, Ruth, Ontology Revisited: Metaphysics in Social and Political Philosophy (London: Routledge, 2014).

Hankins, Thomas L., Science and the Enlightenment (Cambridge: Cambridge University Press, 1985).

Hegel, G.W.F., Lectures on the Philosophy of Religion: Volume I, Introduction and Concept of Religion, ed. by Peter C. Hodgson and trans. by R.F. Brown, P.C. Hodgson \& J.M. Stewart (Berkeley: University of California Press, 1984). On Christianity: Early Theological Writings, trans. by T.M. Knox (New York: Harper Torchbooks, 1961). Phenomenology of Spirit, trans. by A.V. Miller (Oxford: Oxford University Press, 1977).

Hume, David, A Treatise of Human Nature. (London: John Noon, 1739). An Enquiry Concerning Human Understanding, ed. by Tom L. Beauchamp (Oxford: Oxford University Press, 1999). , Dialogues Concerning Natural Religion, ed. by Norman Kemp Smith (New York: The Bobbs-Merrill Company, Inc., 1947). , The Natural History of Religion in The Philosophical Works of David Hume, vol. 4 (London: Charles Tait, 1826).

Inglis, John, Spheres of Philosophical Inquiry and the Historiography of Medieval Philosophy (The Netherlands: Brill, 1998).

Kant, Immanuel, Critique of Practical Reason, trans. by Werner S. Pluhar (Indiana: Hackett Publishing Co., Inc. 2002).

Critique of Pure Reason, trans. by Marcus Weigelt (London: Penguin Books, 2007). Kant's Prolegomena to Any Future Metaphysics, ed. Paul Carus (Chicago: Open Court Publishing Company, 1912). Observations on the Feeling of the Beautiful and Sublime and Other Writings, ed. by Patrick Frierson and Paul Guyer (Cambridge: Cambridge University Press, 2011). Religion within the Boundaries of Mere Reason and Other Writings, ed. and trans. by Allen Wood \& George di Giovanni (Cambridge: Cambridge University Press, 1998).

Leo XIII, "Aeterni Patris: Encyclical of Pope Leo XIII on the Restoration of Christian Philosophy," in The Holy See (4 August 1879), $<$ https://w2.vatican.va/content/leoxiii/en/encyclicals/documents/hf 1-xiii enc 04081879 aeternipatris.html>.

Lilla, Mark, The Stillborn God: Religion, Politics and the Modern West (New York: Random House 2008).

MacIntyre, Alasdair, After Virtue: A Study in Moral Theory (Indiana: University of Notre Dame Press, 2007).

(C) 2016 Jovito V. Cariño http://www.kritike.org/journal/issue 19/carino december2016.pdf ISSN 1908-7330 
God, Philosophy, Universities: A Selective History of the Catholic Philosophic Tradition (London: Rowman and Littlefield Publishers Inc., 2009).

The Tasks of Philosophy: Selected Essays, Volume I (Cambridge: Cambridge University Press, 2006).

Three Rival Versions of Moral Enquiry: Encyclopedia, Genealogy, and

Tradition (Indiana: University of Notre Dame Press, 1990).

Whose Justice? Which Rationality? (Indiana: University of Notre Dame Press, 1988).

McCool, Gerald A., Nineteenth Century Scholasticism: The Search for a Unitary Method (New York: Fordham University Press, 1989).

Moore, G.E., Principia Ethica (New York: Prometheus Books, 1988).

Newton, Isaac, Philosophical Writings, ed. by Andrew Janiak (Cambridge: Cambridge University Press, 2004).

Novotny, Daniel D., Beings of Reason: A Study in Scholasticism of the Baroque Era (Ph.D. Dissertation, New York: State University of New York, 2008).

Orwin, Clifford \& Nathan Tarcov, eds., The Legacy of Rousseau (Chicago: The University of Chicago Press, 1997).

Pereira, Jose, Suarez: Between Scholasticism and Modernity (Wisconsin: Marquette University Press, 2006).

Rawls, John, Political Liberalism, expanded edition (New York: Columbia University Press, 2005).

Reill, Peter Hanns and Ellen Judy Wilson, Encyclopedia of the Enlightenment (New York: Facts on File, Inc., 2004).

Rousseau, Jean-Jacques, Emile or on Education, trans. by Allan Bloom (USA: Basic Books, 1979). La Nouvelle Héloïse: Julie, or the New Eloise: Letters of Two Lovers, Inhabitants of a Small Town at the Foot of the Alps, trans. by Judith $\mathrm{H}$. McDowell (Pennsylvania: The Pennsylvania State University Press, 1987).

The Discourses and Other Early Political Writings, ed. by Viktor Gourevitch (Cambridge: Cambridge University Press, 1997).

Rozenweig, Franz, The Star of Redemption, trans. by Barbara E. Galli. (Wisconsin: The University of Wisconsin Press, 2005).

Russell, Bertrand, History of Western Philosophy (London: Taylor \& Francis Group, 2005).

Schleiermacher, Friedrich, On Religion: Speeches to its Cultural Despisers, trans. and ed. by Richard Crouter (Cambridge: Cambridge University Press, 2003).

Schmidt, Claudia M., David Hume: Reason in History (Pennsylvania: The University of Pennsylvania Press, 2003).

(c) 2016 Jovito V. Cariño http://www.kritike.org/journal/issue 19/carino december2016.pdf ISSN 1908-7330

(c) $)$ BY-NC-ND 
Schouls, Peter A., Descartes and The Enlightenment (United Kingdom: Edinburgh University Press, 1989).

Shank, J.B., The Newton Wars and The Beginning of The French Enlightenment (Chicago: The University of Chicago Press, 2008).

Stevenson, Charles L., Ethics and Language (New Haven: Yale University Press, 1958).

Taylor, Charles, Philosophy and the Human Sciences: Philosophical Papers 2. (Cambridge: Cambridge University Press, 1985). 